\title{
The Book as Shrine, the Badge as Bookmark: Religious Badges and Pilgrims' Souvenirs in Devotional Manuscripts
}

\author{
Hanneke van Asperen
}

During the latter part of the fifteenth century, metal badges were frequently attached to religious manuscripts. The objects were often removed at a later date, but traces found in the parchment - impressions, metal residue, and sewing holes or adhesive - reveal their former presence. ${ }^{1}$ Traces of these badges are omnipresent, but often misinterpreted, overlooked or ignored in manuscript catalogues. The growing interest in the common practices of readers and their interaction with books has led scholars increasingly to focus their attention on badges that were attached to parchment. Megan Foster-Campbell has suggested that these inserted badges were used as instruments for the devotional exercises of mental pilgrimage. ${ }^{2}$ For some book owners, pilgrims' badges must have been mementos of their own journey and it is tempting to interpret them as devotional aids that would help the devotee to re-visit the site of pilgrimage in the mind. This interpretation, however fascinating, deserves some scrutiny, for the context of the badge changed when it moved from the pilgrim's bag to the book of the stay-at-home. The badges often served more practical purposes.

1 The few surviving examples of books with metal badges still extant include: Chantilly, Musée Condé, Impr. xIV. C. 3; Olim, Bonn Bad Godesberg, collection Hermann Kunst MS 5 (current whereabouts unknown); Olim, Cologne, auction house Venator \& Hanstein, 25 March 2000, Lot 572 (current whereabouts unknown); Olim London, Christie's, 24 November 2007, Lot 10 (current whereabouts unknown); Oxford Bodleian Library, MS Douce 51; Paris, Bibliothèque de l'Arsenal, MS 1176 rés; The Hague, National Library of the Netherlands, MS 77 L 6o; Vienna, Österreichische Nationalbibliothek, MSs Series nova 2596, 2624 and 12 897. Cf. Asperen H. van, Pelgrimstekens op Perkament. Originele en Nageschilderde Bedevaartssouvenirs in Religieuze Boeken ( ca 1450 - ca 1530), Nijmeegse Kunsthistorische Studies 16 (Ede: 2009).

2 Foster-Campbell M.H., "Pilgrimage through the Pages: Pilgrims' Badges in Late Medieval Devotional Manuscripts", in Blick S. - Gelfand L.D. (eds.), Push Me, Pull You. Imaginitive, Emotional, Physical, and Spatial Interaction in Late Medieval and Renaissance Art (Leiden: 2011) 227-274.

(C) HANNEKE VAN ASPEREN, 2019 | DOI:10.1163/9789004375888_016

This is an open access chapter distributed under the terms of the prevailing CC-BY-NC-ND License at the time of publication. 


\section{Religious Badges and Pilgrimage Souvenirs}

In an article called Sewing the Body of Christ, Kathryn Rudy recently counterargued that not all metal badges in books were pilgrimage souvenirs and she has subsequently suggested that some of these may have been souvenirs of the taking of Communion. ${ }^{3}$ She called these wafer badges or ersatz hosts. One of the arguments she used in support of the identification of host souvenirs was the round impressions that many badges left in the parchment. Rudy sets the round offsets in the parchment alongside surviving cast badges in all shapes and sizes.

However, books did not contain cast badges. From the research so far, we know that only stamped badges were attached to books and these were usually round. The production of stamped pilgrims' souvenirs is documented in church accounts from various sites of pilgrimage in the second half of the fifteenth and early sixteenth centuries. ${ }^{4}$ As numbers of pilgrims grew, so did the demand for badges, and more, and different kinds of objects were added to the merchandise available at cult sites. Around the 1450s, silversmiths and goldsmiths took up the technique of stamping images on thin sheets of metal usually copper alloy or silver - for the production of badges. ${ }^{5} \mathrm{~A}$ printed book of hours, published by Egidius Hardouin around 1515, contains two round pilgrims' badges, one from Le Puy and one from Saint-Claude [Fig. 14.1]. ${ }^{6}$ The first shows the Virgin and Child under a canopy flanked by St Anthony Abbot on her right and a bishop on her left. The other badge depicts St Claude enthroned. It is also true that the badges that have left identifiable impressions in the parchment were often demonstrably pilgrims' souvenirs. For example, a book of hours, probably produced in Hainaut, has impressions of several badges that cannot all be identified [Fig. 14.2]. Those that are identifiable depict the miraculous consecration of the chapel of the Virgin in Einsiedeln, St Adrian (venerated in Geraardsbergen), St Quentin (of Saint-Quentin), and the head

3 Rudy K.M., "Sewing the Body of Christ: Eucharistic Wafer Souvenirs Stitched to FifteenthCentury Manuscripts Primarily in the Netherlands", Journal of the Historians of Netherlandish Art 8, 1 (2016), DOI: 10.5092/jhna.2016.8.1.1.

4 E.g. De Mecheleer L., Rekeningen van de Kerkfabriek van de Sint-Leonarduskerk van Zoutleeuw (1405, 1452-1599) (Brussels: 1997); Vorsterman van Oyen G.A., Het Archief van Aardenburg (Middelburg: 1889); Koldeweij A.M., "Reliekhoofden en Pelgrimstekens. Nieuws over de Utrechtse Zilversmid Cornelis van Noert”, in Rijen J.-P. van - Bergh-Hoogterp L.E. van den Roessingh J.R.H. (eds.), De Stavelij in Zilver: 25 Jaar Zilverclub (S.1.: 2000) 31-37; Deys H.P., "De Pelgrimsinsignes van Sinte Cunera te Rhenen", Jaarboek Oud-Utrecht 67 (1994) 33-54.

5 Asperen, Pelgrimstekens op Perkament 92.

6 Asperen, Pelgrimstekens op Perkament 319-320. 


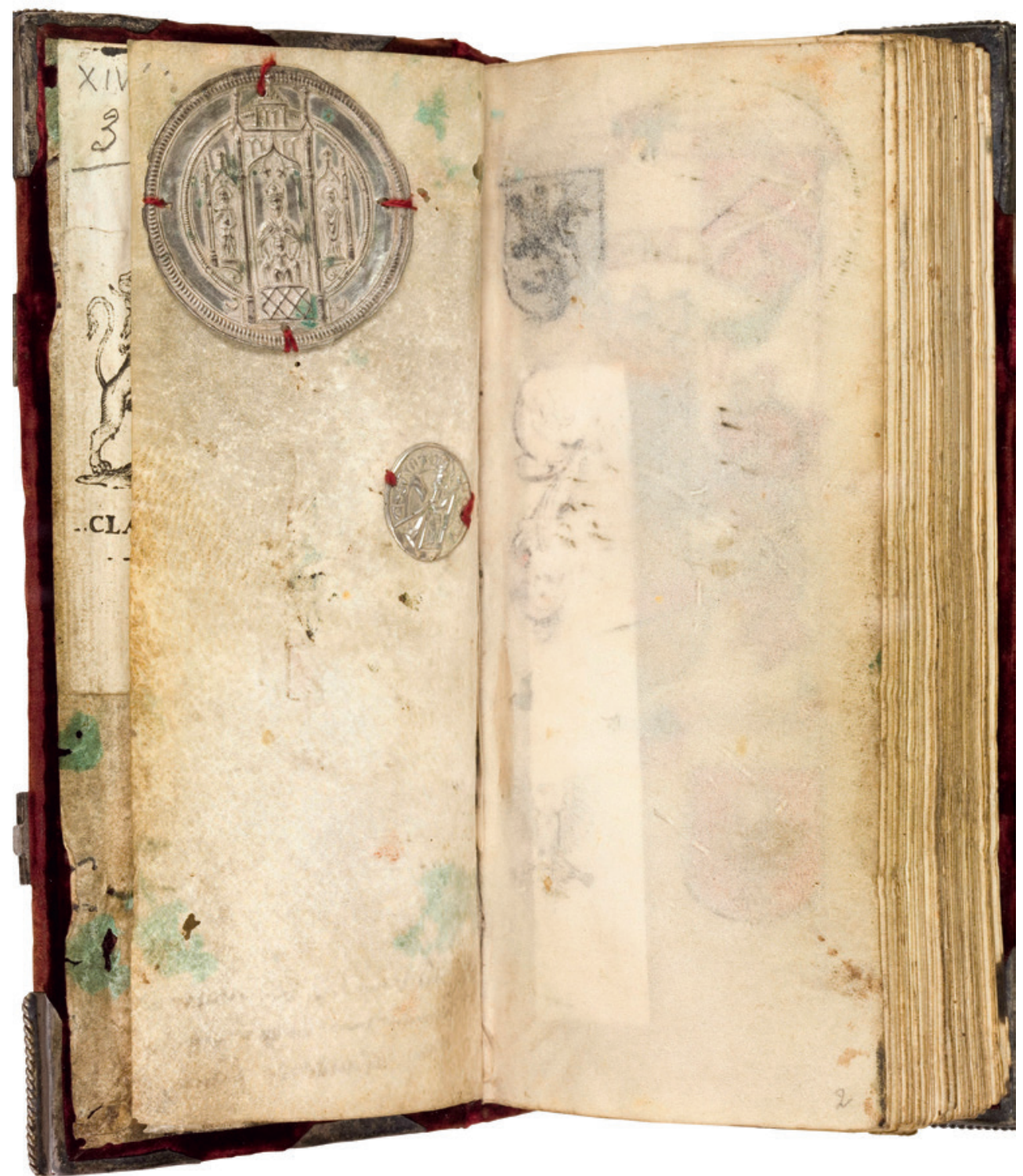

FIGURE 14.1 Two pilgrims' badges, one of Le Puy (45 mm) and one of Saint-Claude (19 mm), added to the blank folios of a printed book of hours (Paris, Egidius Hardouin: ca. 1515). Chantilly, Musée Condé, Impr. XIV C.3, fols. 1v-2r PHOTO (C) CNRS - IRHT (INSTITUT DE RECHERCHE ET D'HISTOIRE DES TEXTES) 


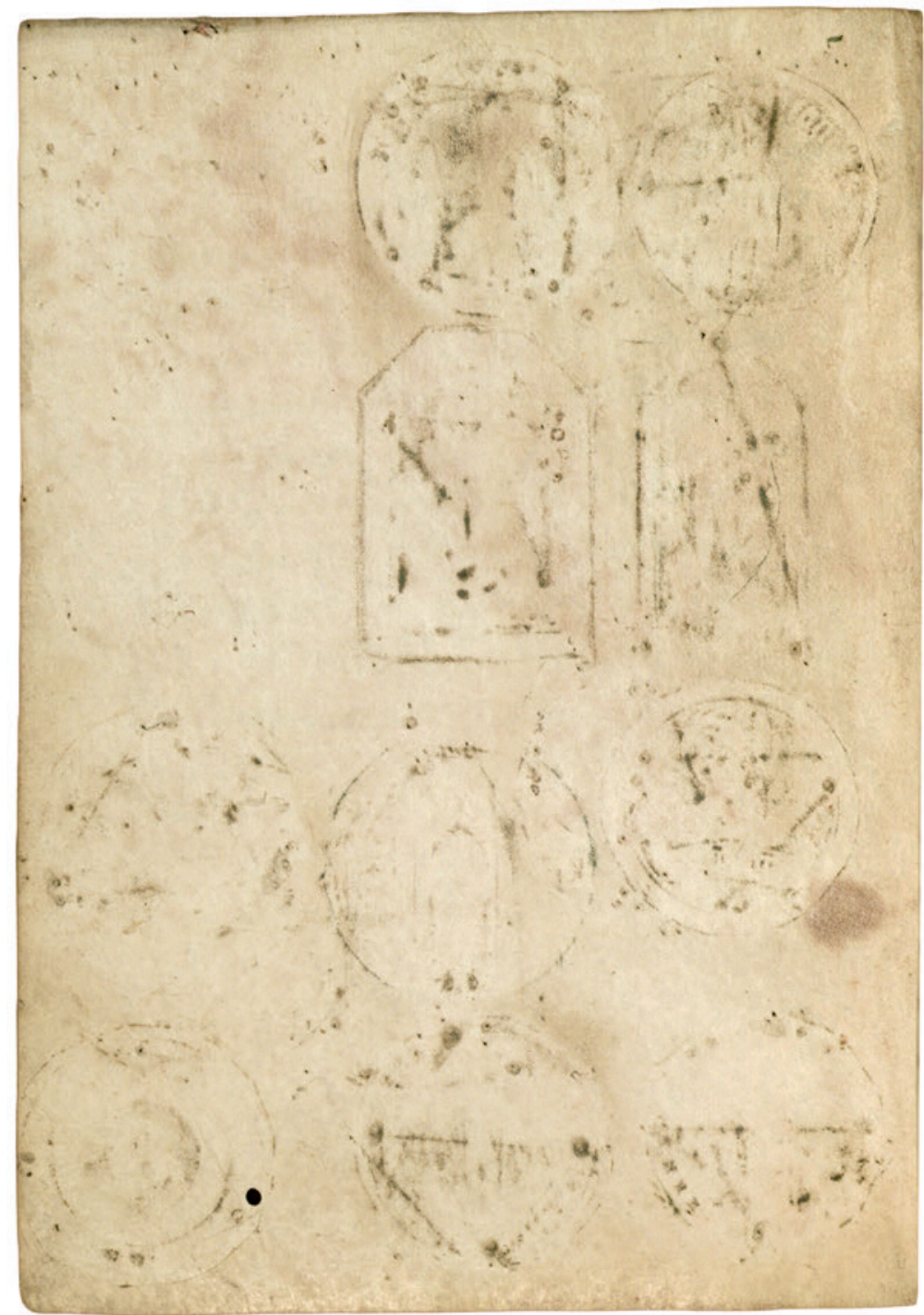

FIGURE 14.2 Blank flyleaf with partly readable impressions of badges from Einsiedeln (Engelweihe), Geraardsbergen (St Adrian), Le Puy (the Virgin), Saint-Quentin (St Quentin), and Amiens (St John the Baptist) among others, in a prayerbook, including the Hours of the Holy Cross (possibly Hainaut: ca. 1440). Baltimore, Walters Art Museum, MS W 218, fol. 6v. Image in the public domain 
of St John the Baptist (possibly from Amiens). Most of these badges, though maybe not all of them, were bought at sites of pilgrimage.

Kathryn Rudy nuanced the general assumption that all badges in books were pilgrimage souvenirs. They are not. Some of them were badges with images that are not necessarily tied to a location, but depict widely venerated saints, for example Catherine, Barbara or Christopher, or generally known cults that were sometimes coupled with large indulgences, such as the Virgin in the sun and the Veronica. ${ }^{7}$ These badges could be bought from local craftsmen or travelling merchants at sites of pilgrimage or at home, during fairs for example, and it is difficult to assert exactly when and where these badges would have been purchased because they do not bear a reference to a site of origin and could have been purchased anywhere. ${ }^{8}$ With this nuance regarding the provenance of badges in mind, the conclusion must be that while most badges in books were pilgrims' souvenirs that can be tied to a specific location, some had images that are not connected to a localized cult. These latter badges depicted popular religious imagery and this justifies a reconsideration of badges as aids for mental pilgrimage.

\section{The Book as Treasure Chest}

Stamped badges differ from the traditional cast badges that had been produced from the twelfth century onwards, not so much in their imagery, but more so in their weight, shape and size. ${ }^{9}$ Indicatively, after stamped badges were added to the supply of pilgrims' souvenirs on sites of pilgrimage, cast badges also remained on offer. In 1521, the church factory of Zoutleeuw, for example, ordered 1250 stamped latten badges, 450 stamped silver ones and 11 dozen cast badges

7 Van Asperen H., "Où il y a une Veronique attachiée dedens: Images of the Veronica in Religious Books", in Murphy A. - Kessler H.L. (eds.), The European Fortune of the Roman Veronica in the Middle Ages, Convivium Supplementum 2 (Leiden: 2018) 232-249.

8 For example Kunera, Database of Medieval Badges and Ampullae, Radboud University Nijmegen /CKD, nos 14098 (cast badge of the Veronica), 16370 (cast badge of the Virgin on the crescent), and 16748 (cast badge of the Virgin in the sun), <http://www.kunera.nl > [consulted 2 December 2016].

9 The first mention of cast pilgrims' souvenirs seems to be that of Guernes de Pont-SteMaxence in his life of St Thomas Becket, completed in 1174. There, he writes about the ampullae of Canterbury, shells from Santiago and pewter badges from Rocamadour. For many examples of cast and stamped badges and to compare the two, see Kunera, <http://www .kunera.nl>. 
to sell to pilgrims. ${ }^{10}$ Both the cast and the stamped badges of Zoutleeuw had an image of St Leonard. Because of their specific qualities, the stamped badges facilitated different kinds of usage, for example, inclusion in manuscripts: the books kept these fragile images safe and, in turn, precisely because they are small (usually varying between 20 and $60 \mathrm{~mm}$ ), thin and very lightweight, the badges did not damage the parchment pages. In fact, these stamped badges suited being put in books so well that it could be argued that they might have been introduced precisely for that purpose. They are not suitable for wearing on clothing because the flimsy metal damages easily. Stamped badges needed a specially produced frame if the owner wanted to attach them to a chain or a rosary, but they could be attached to books without any problem. The book kept these images safe, while the badges added value to the book.

Traces of these stamped badges appear almost exclusively in religious manuscripts for devotional use, often books of hours, and sometimes prayer books. ${ }^{11}$ Most of the books with traces of these tiny badges were used often and intensively, as indicated by smudges, darkening of the pages, handwritten notes, added prayers, etc., and the books were mainly in the hands of a layperson at the time when the badges were added. ${ }^{12}$ The observations that badges were (1) added to religious books, (2) that they belonged to lay owners and (3) that they were used intensively, seem to justify the conclusion that badges somehow shaped the daily devotional lives of the laity. The next question then focuses on their function. Why did laypeople add badges to their books? Is the location of the badges in the books indicative of the way they were used?

When adding religious badges, people principally looked for empty pages. ${ }^{13}$ These could be blank folios between the written sections, but often they were the blank flyleaves in the front or back of the book [Figs 14.1, 14.2 and 14.3]. In particular, books that still have their original binding and flyleaves often reveal the former presence of badges. When old flyleaves are gone, the first folio of

\footnotetext{
$10 \quad$ De Mecheleer, Rekeningen 336-339.

11 Asperen, Pelgrimstekens op Perkament 94-108.

12 Ibid.

13 To support the argument that some of these badges must be wafer souvenirs, Kathryn Rudy states that most of these badges were attached to the Hours of the Cross and the Penitential Psalms. As far as we know, most badges were attached to blank pages in books; see Asperen, Pelgrimstekens op Perkament 121-122. If the owners did seek a location next to a text they most often chose sections dedicated to the Virgin (Hours of the Virgin or popular prayers, especially the Obsecro te), not sacramental themes. Second, the surviving badges in books, as well as those impressions that can still be identified, indicate pilgrimage badges, not badges with sacramental themes. It would seem that the mere location of the badges is not sufficient to suggest that some were host souvenirs.
} 


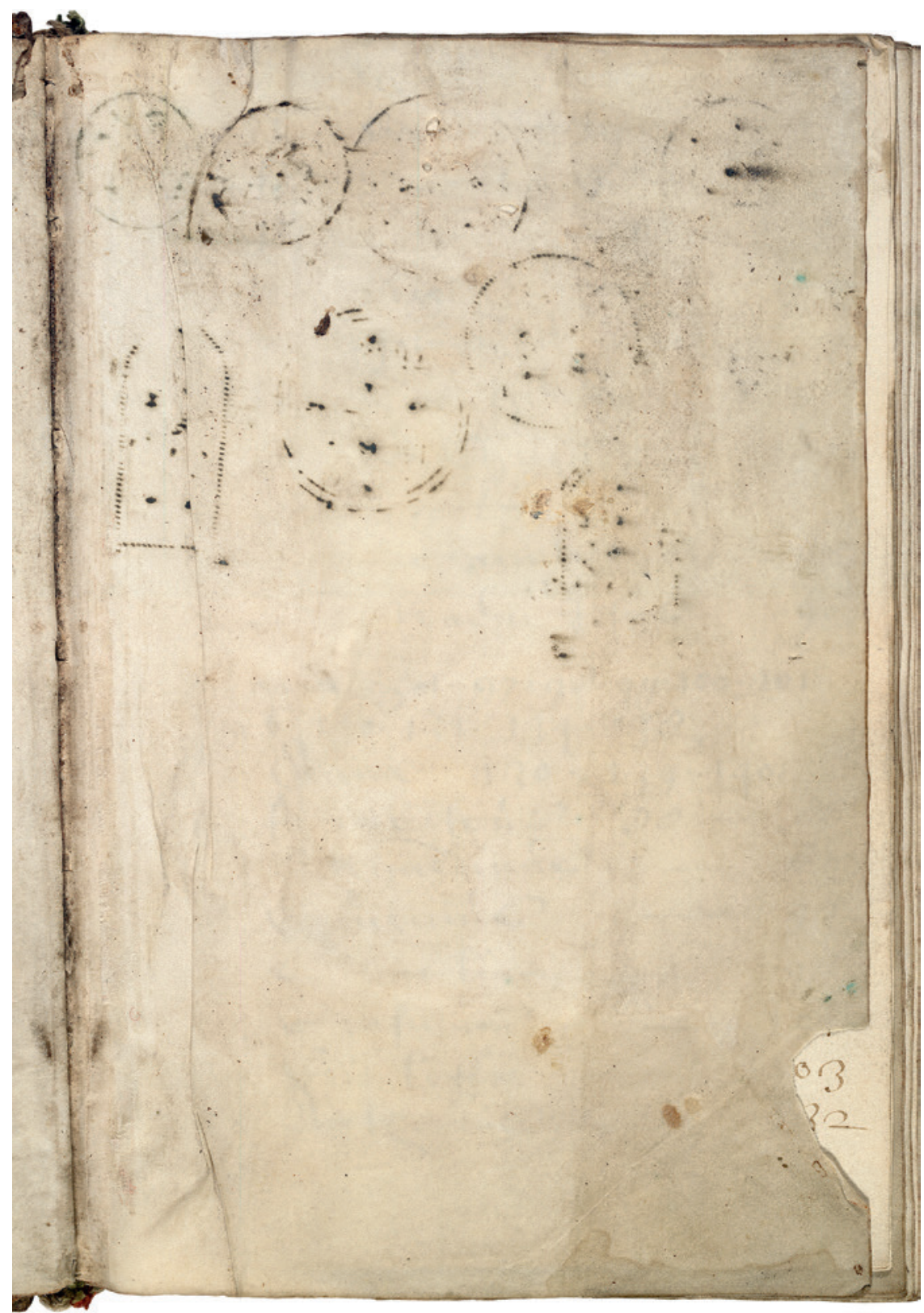

FIGURE 14.3 Blank flyleaf with impressions of unidentified badges in a book of hours (Delft: ca. 1480-1500). The Hague, National Library of the Netherlands, MS $132 \mathrm{G}_{38}$, front flyleaf. Image in the public domain 
books of hours, usually the month of January of the eternal calendar, often reveals impressions of badges that were once sewn to the preceding flyleaf. Often books have been rebound, so flyleaves were removed, together with the badges. Sometimes owners added only one badge to a blank page, but numbers vary, and frequently people sewed in more than one badge.

In some cases, the badges are scattered over the page rather arbitrarily, suggesting that there was no plan, no careful arrangement. The owner of a Delft book of hours probably collected the badges over a longer period of time, adding the badges at the moment of purchase or whenever he or she received them [Fig. 14.3]. But usually the badges were carefully organized [Fig. 14.2]..$^{14}$ Book owners seem to have collected the badges first - most likely over a longer period of time - before adding them. The badges were then arranged according to shape and size, sometimes even with regard to the material [Fig. 14.4]. In this last book of hours, possibly from Hainaut, the owner alternated copper and silver badges to create a colorful margin to the prime of the Hours of the Virgin. Here, it seems to be the arrangement of the material that mattered most. ${ }^{15}$ The badges do not illustrate the texts, however. They were not attached next to the miniatures of the Virgin and St Claude. Instead, the owner chose to keep them together and attach them to a separate page as many book owners did [Fig. 14.1]. In this way, the badges frame the book as a whole.

It was the religious content of the book which made it an appropriate container for religious objects of personal value, on any page, just as a wooden chest or textile pouch could hold precious items. Charlotte of Savoye (14411483), wife of King Louis XI, owned such a purse 'of white and red satin with a bag of St James and mutiple lead badges inside. ${ }^{16}$ Another example is mentioned in an inventory of 1567 which attests that shoemaker Cornelis Jansz, also called Schroye, from Bergen op Zoom kept 'a box of various white badges and five gilt badges, a gilt medal and several other items' in his bedroom. ${ }^{17}$ During

14 Asperen, Pelgrimstekens op Perkament 121-126. Rudy also noted that all ' $\mathrm{t}]$ ] he badges were not, in other words, affixed haphazardly but with an end goal in mind.' Rudy, "Sewing the Body" 5 .

15 This was also the case in Walters Art Museum, MS W 234, fol. $17 \mathrm{v}$.

16 Inventory of Charlotte of Savoye of 1483 : 'une bourse de satin blanc et roge en la quelle a dedans une gibecière de $\mathrm{S}$. Jacques et plusieurs enseignes de plombs', as mentioned in Spencer B.W., Pilgrim Souvenirs and Secular Badges, Medieval Finds from Excavations in London 7 (London: 1998) 20; Gay V., Glossaire Archéologique du Moyen-Âge et de la Renaissance, vol. 1 (Paris: 1887) 635 .

17 Enno van Gelder H.A., Gegevens Betreffende Roerend en Onroerend Bezit in de Nederlanden in de 16e Eeuw (The Hague:1972-1973) 71, no. 177. 'een dooze met diversche witte teeckenen ende vijff vergulde teeckenen met eenen vergulden penninck ende andere cleynicheyt'. 


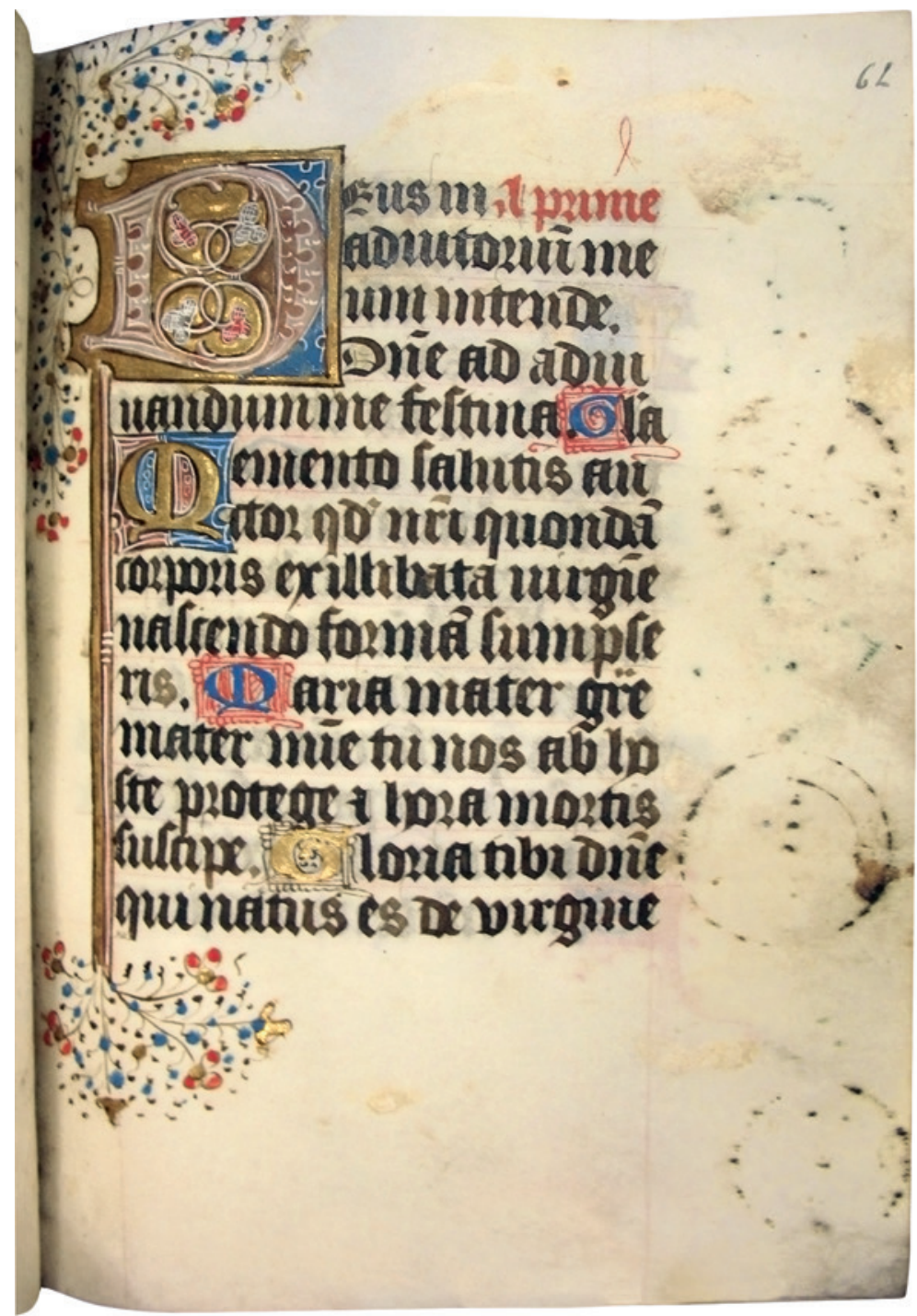

FIGURE 14.4 Opening pages of prime of the Hours of the Virgin with impressions of silver and latten badges, in a book of hours (possibly Hainaut: fifteenth century). Bruges, Public Library 'De Biekorf', MS 329, fols. 61v-62r PHOTO BY THE AUTHOR 
private moments, the owner could open the chest, pouch or book to look at the badges and contemplate their images, perhaps combining contemplation with suitable prayers.

In her much cited works, Mary Carruthers has pointed out the metaphor of the thesaurus or scrinium to explain the working of memory. ${ }^{18}$ Education, and especially the study of books, is the storage of knowledge. In the same way that an ark, a chest, and a library are all used to store manuscripts, the memory keeps and structures pictures and texts and the art of memory was a craft in which text and images played complementary and inseperable roles. In a sense, the shrine also became a metaphor for the book itself. As with memory, the book was considered something organic that was continuously re-modelled and re-sized to fit the devotional life of its owner better. Because of the associations of books with shrines of knowledge and knowledge with word and image, devotional books were easily turned into physical containers of prayers and religious pictures. Small two-dimensional items of devotional value, such as prayers, prints, drawings and badges, are then stored alongside other images and texts in the religious book. As a shrine or chest filled with religious treasure, continuously growing, the book was expanded and added to with religious text and religious images, both necessary elements for carefully shaping devotional lives.

The idea of the book as a repository of devotional objects - well-structured in the same way that knowledge should be stored in the memory in order to be retrievable ${ }^{19}$ - was reiterated in Flemish books where illuminators painted trompe-l'oeil images of inserted badges [Fig. 14.5]. The painter did not just create the illusion of added badges; they also painted a wooden frame. These painted badges enhance the idea of the book as a cabinet, or shrine, for devotional items, where the badges are carefully arranged according to their shape and material. The arrangement reflects the idea of the border of alternating copper and silver badges in the margin of the pages for prime in the book of hours in Bruges [Fig. 14.4]. In the illusionistic margin, as in the Bruges book, gold alternates with silver, so that the badges create a decorative border for the miniature. The big difference is that the badges in the illusionistic margins were not personal: they stemmed from the model leaves of the illuminator, and were used and re-used in books for different audiences. The badge motifs therefore reflect the types of badges that would have circulated in the orbit

\footnotetext{
18 Carruthers M., The Book of Memory: A Study of Memory in Medieval Culture (Cambridge New York: 1992) 37-55, esp. 47.

19 Carruthers, The Book of Memory 56.
} 


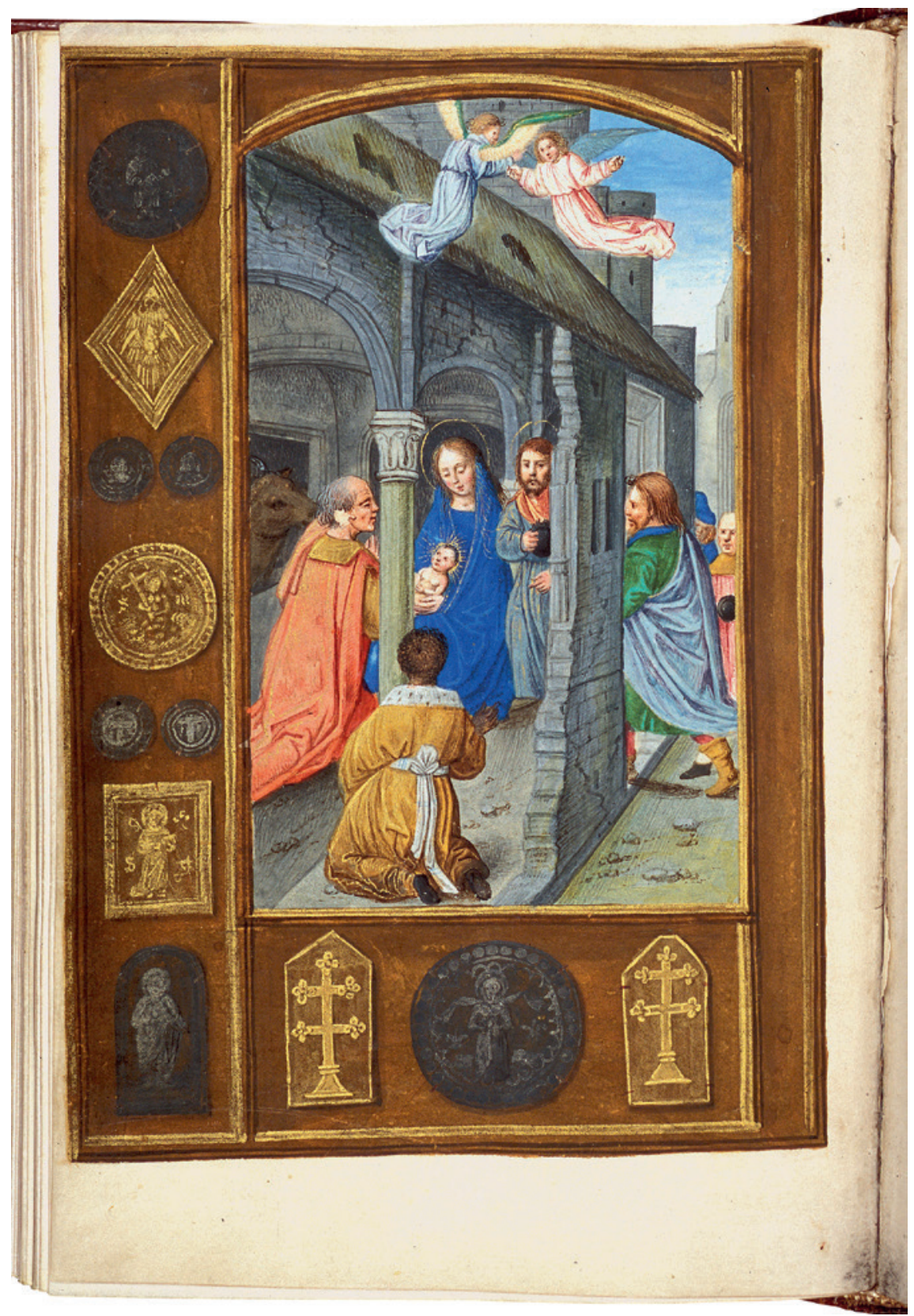

FIGURE 14.5 Master of the Musgrave Hours, Adoration of the Magi, surrounded by a badge border, in a book of hours for the Use of Rome, Flemish (possibly Bruges: ca. 1500-1525). The Hague, Museum Meermanno | House of the Book, $\mathrm{MS} 10 \mathrm{E} 3$, fol. gov. Image in the public domain 
of the illuminator rather than a choice of the future book owner, or even the book's intended destination. Nevertheless, the illusionistic wooden frame with the 'inserted' badges embroiders on the same associations that made devotees attach badges in the first place: the concept of the book as thesaurus.

In contrast to the illusionistic badge border, an owner could use badges to add a section of personal devotion to the otherwise often standard book of hours. Although it is beautifully designed, the printed book of hours with badges of Le Puy and Saint-Claude [Fig. 14.1] is the product of serial production for a wide, though well-off, audience. The printed parts of the book make no reference to the intended owner, but simply contain the standard elements such as an almanac, the Gospel extracts, the Hours of the Virgin, of the Cross, and of the Holy Spirit, the Penitential Psalms, the Office of the Dead and popular prayers to the Virgin and the saints. To customize this luxurious, but standard book, the owner added a personal quire of handwritten prayers and miniatures after the book's production was completed around 1515 (Appendix). He had it made to order. The owner, dressed in the tunic of Chilly, kneels in one of the miniatures where he is presented to the Virgin by Cardinal Louis Allemand who had died in 1450 [Fig. 14.6]. The coat of arms of Allemand is prominently included in a miniature of the coats of arms of De Chilly's family's ancestry (fol. 3 r), so he was probably related and this would explain the prominent inclusion of the beatus who would not make it to sainthood. Allemand was never sanctified. It seems that the quire was added shortly before or shortly after the beatification in 1527. This highly personal, custom-made section contains a few prayers, all dedicated to the Virgin, St Claude or Louis Allemand. Clearly these pilgrims' badges suited the owner's personal devotional preferences for the Virgin and St Claude which are attested to in the first quire of the book.

\section{An Instrument of Mental Pilgrimage?}

When badges are still present, as in the book of De Chilly, it becomes clear that the empty pages of books were turned into veritable devotional panels or diptychs that were geared to personal preferences. Were these badges used to make the act of remembering a former pilgrimage into a personal devotional exercise? While this is surely in the realm of possibility, we need to make one clarification: the owner of the book was not necessarily the same person as the pilgrim who had taken the badges home. Badges were often used as gifts. The accounts of highly-placed persons mention badges being distributed among people of the household. Duke Philip the Good of Burgundy bought badges 'to 


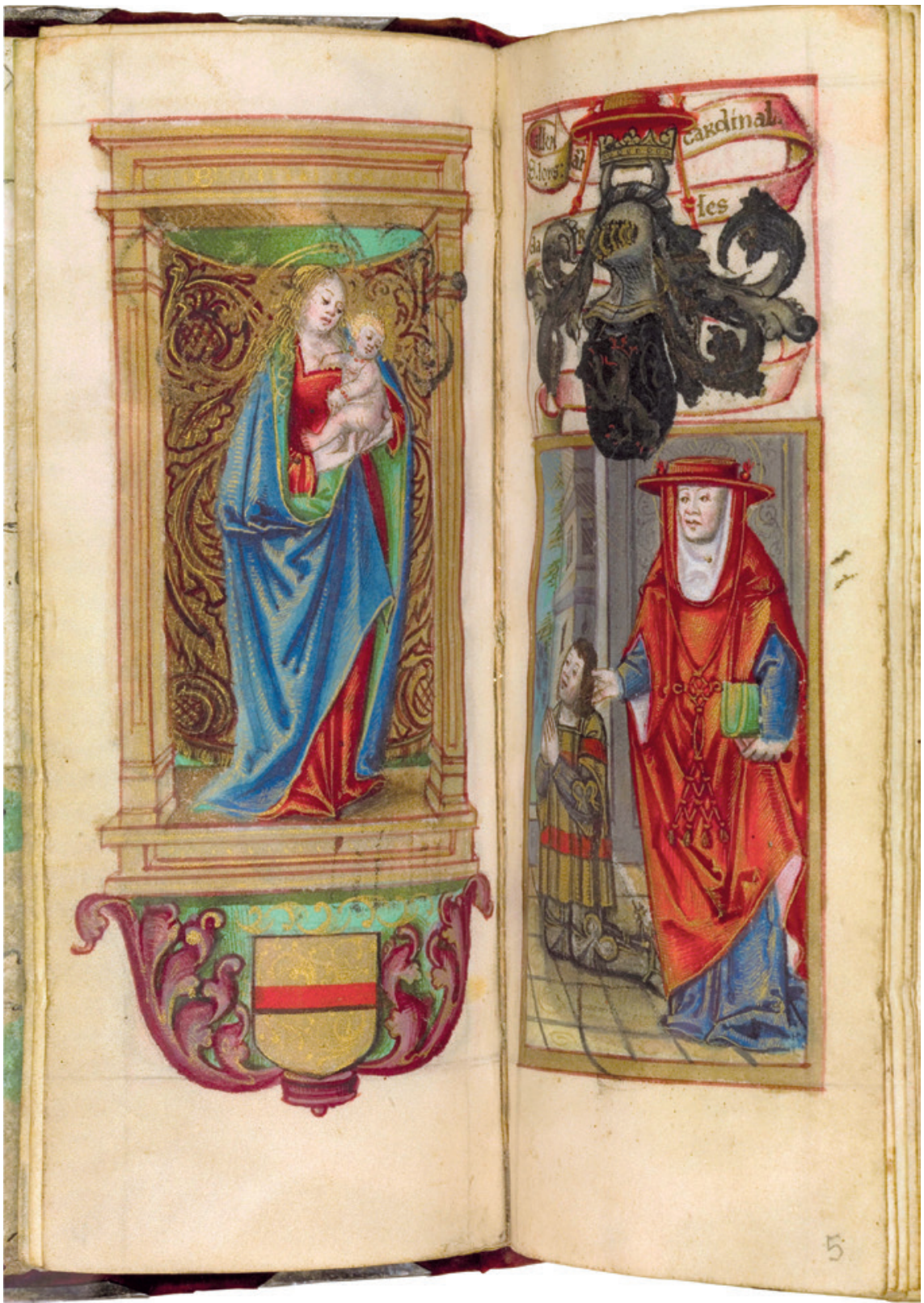

FIGURE 14.6 Miniatures of the Virgin and Child and a knight of Chilly, probably a member of the Du Tartre family, presented by Louis Allemand, a printed book of hours (Paris, Egidius Hardouin: ca. 1515-1530). Chantilly, Musée Condé, Impr. XVI C.3, fols. $4 \mathrm{~V}-5 \mathrm{r}$ PHOTO (C) CNRS - IRHT (INSTITUT DE RECHERCHE ET D'HISTOIRE DES TEXTES) 
distribute among the people of his household: ${ }^{20} \mathrm{He}$ used these to accentuate the established hierarchy at court. In 1420-21, he bought badges of the Virgin of Boulogne, some gilt and others plain silver, for his wife, for the knights, esquires, and officers of his court, and for the women in his wife's entourage. ${ }^{21}$ In 1451, René of Anjou bought large golden (or more probably gilt) badges of St Catherine of Fierbois from goldsmith Jean Juliot for himself, his wife and his daughter Yolande, small golden ones for the chamberlains, large silver ones for the 'gentilzhommes and demoiselles' and small ones for the officers. ${ }^{22}$ These gifts, which were an important part of court culture, served different purposes. $^{23}$ They compelled gratitude and loyalty. Moreover, they were intended to tie subjects to their lord. The accounts of Burgundy and Anjou also demonstrate that badges were used as gifts for close relatives: during the $145 \mathrm{os}$, Duke Philip bought one golden badge of St Catherine of Fierbois 'par lui achettée pour madicte dame [his wife]. ${ }^{24}$

Similar documents recounting the distribution of badges to family members do not exist for people of lower status, but pilgrims of more modest means could also buy badges, although obviously not the expensive gilt ones. The accounts of pilgrimage churches mention badges of different value to suit all purses, large and small, from expensive silver, or silver gilt, to cheap latten ones. ${ }^{25}$ They were tokens of affection. The giver wanted to show where he or she had been, and hoped that the badge would keep loved ones safe. After being passed on to others, they continued to function as charms and instruments of devotion. Given that some badges were gifts before insertion into a book, and the subsequent conclusion that a book owner was not necessarily the pilgrim, the badge could not always have been used to meditate on a completed physical pilgrimage.

An exercise of mental pilgrimage does not imply the memory of a physical pilgrimage. As a devotional exercise, a mental pilgrimage could take many shapes and forms depending on the devotee's aspirations and desires, and the opportunities open to them. Time-consuming and detailed versions involved

20 De Laborde L., Les Ducs de Bourgogne. Études sur les Lettres, les Arts et l'Industrie pendant le XVe Siècle et plus particulièrement dans les Pays-Bas et le Duché de Bourgogne, vol. 2, part 2 (Paris: 1851) 386-387.

21 De Laborde, Les Ducs de Bourgogne, vol. 2, part 1 (Paris: 1849) 181, no. 5.

22 Arnaud D'Agnel G., Comptes du Roi René (Paris: 1910) 286, no. 853.

23 Perkinson S., "Likeness, Loyalty, and the Life of the Court Artist: Portraiture in the Calendar Scenes of the Très Riches Heures”, in Dückers R. - Roelofs P. (eds.), The Limbourg Brothers: Reflections on the Origins and the Legacy of Three Illuminators from Nijmegen (Leiden: 2009).

24 De Laborde, Les Ducs de Bourgogne, vol. 2, part 3 (Paris: 1852) 354, no. 6737.

25 Cf. De Mecheleer, Rekeningen; Vorsterman van Oyen, Het Archief 68-70. 
a mental journey through different sites. These mental 'journeys' usually focused on Rome or Jerusalem. There are examples of cloistered women walking through the convent imagining Christ's Passion. ${ }^{26}$ Each distance covered would involve as many steps as Christ took on his way to Calvary. Different locations within the convent were mentally transformed into significant sites in biblical Jerusalem. In other versions of mental pilgrimage, steps were replaced with prayers, and the devotee would say as many prayers as the pilgrim would have taken steps.

These exercises of mental pilgrimage were popular with cloistered men and women, but the exercises were not necessarily restricted to convents. ${ }^{27}$ Although there are exceptions, many lay people might have preferred less time-consuming versions and another form of mental pilgrimage did not focus on the journey, but on the destination. For this reason, some people added prayers explicitly addressed to cult images to their books so that they could profit from the salvific dynamics of the cult statue without leaving the house. No journey, physical or mental, was needed, just a relocation in the mind. A prayer by Guillaume Alexis, or related versions, was associated with the image of the Virgin of Le Puy. The devotee addresses the Queen of Heaven who is 'seated up there on a divine throne in this present church [...] I have come to you this morning as your pilgrim, with bowed head. Humbly I offer you my body and my soul, so that at my end [sc. at the end of my life] you would like to be present'.28 The pilgrimage - although it is an imaginary one - is used to

26 There is a whole body of texts on mental pilgrimage in convents. A selection: Rudy K.M., Virtual Pilgrimages in the Convent: Imagining Jerusalem in the Late Middle Ages (Turnhout: 2011); Asperen H. van, “'As If They Had Physically Visited the Holy Places': Two Sixteenth-Century Manuscripts Guide a Mental Journey through Jerusalem (Nijmegen University Library, Mss 205 and 233)", in Goudeau J. - Verhoeven M. - Weijers W. (eds.), The Imagined and Real Jerusalem in Art and Architecture (Leiden: 2014) 190-214; Beebe K., "Reading Mental Pilgrimage in Context: The Imaginary Pilgrims and Real Travels of Felix Fabri's 'Die Sionpilger”, Essays in Medieval Studies 25 (2008) 39-70; Ehrenschwendtner M.-L., "Virtual Pilgrimages? Enclosure and the Practice of Piety at St Katherine's Convent, Augsburg", Journal of Ecclesiastical History 6o, 1 (2009) 45-73.

27 Rudy, Virtual Pilgrimages 240-252; Rudy K.M., "A Guide to Mental Pilgrimage: Paris, Bibliothèque de l'Arsenal Ms. 212", Zeitschrift für Kunstgeschichte 64, 6 (2000) 494-515.

28 Paris, Bibliothèque nationale de France, MS Latin 1370, fol. 39v: 'O Royne qui fustes mise, Et assise, Lassus ou [ sic] throne diuine En ceste presente eglise Sans faintise. Suys venu a ce matin Comme vostre pelerin. Chef enclin Humblement je vous presente, Mon corps et mon ame [4or] a fin, Qua ma fin Vous veuillez estre presente.' Cf. Reinburg V., "Hearing Lay People's Prayer", in Diefendorf B.D. - Hesse C. (eds.), Culture and Identity in Early Modern Europe (1500-180o): Essays in Honor of Natalie Zemon Davis (Ann Arbor: 1993) 20-40, here 27 . 
prefigure a visit by the Virgin to the pilgrim in the hour of death. According to the prayer text, the devotee is a pilgrim. In a book of hours, the owner coupled this prayer with a miniature of the black Virgin of Le Puy to make it easier for devotees to picture themselves in front of the statue. ${ }^{29}$

Since the badge represented the cult image at the cult site, the devotee could theoretically use the badge to mentally visit that place, whether they had been there themselves or not. For those devotees who could not afford a personalized book, pilgrims' badges might have been an easy way to add a focus on a cult image to their standard books. If the badges were used to address a cult statue, a contemplation of the image was most likely accompanied by a prayer. Thus, if badges were attached next to a suitable text, mental exercise may have been a motive for the book owner.

\section{$4 \quad$ Badges as Bookmarks}

Some pilgrims' badges might have been coupled with prayer in order to perform an exercise of mental relocation, but this does not mean every pilgrims' badge, even those placed next to religious texts, had such a purpose. As stated above, often badges have no direct connection with the text that they accompany. In a book that was produced in the east of the Netherlands [Fig. 14.7], four badges were attached in different places within the book. There are traces of one - sewing holes, impressions of relief with metal residue - at the beginning of the popular Hours of the Virgin, at the Hours of the Cross, of the Holy Spirit and the Office of the Dead. Two impressions are unrecognizable. The circular badge that marked the beginning of the Office of the Dead possibly depicted the Virgin. Another circular badge depicted St Quirin, and came from Neuss. Placed on the page immediately preceding the Hours of the Holy Spirit, there seems to be no intended link between the image or the badge's provenance and the text.

All badges are in the outer margin against the edge of the book. More importantly, they were all placed on the verso of an opening with a new incipit. If the user of the book picked up the unfoliated or unpaginated book, the badges would have served as visible and perceptible bookmarks. A mark on the lefthand side of the book would have suited the dextral devotee who would use

29 On a prayer book with an image of, and a prayer to the Virgin of Le Puy, see Reinburg V., French Books of Hours: Making an Archive of Prayer, c. 1400-160o (Cambridge: 2012) 229-235. 


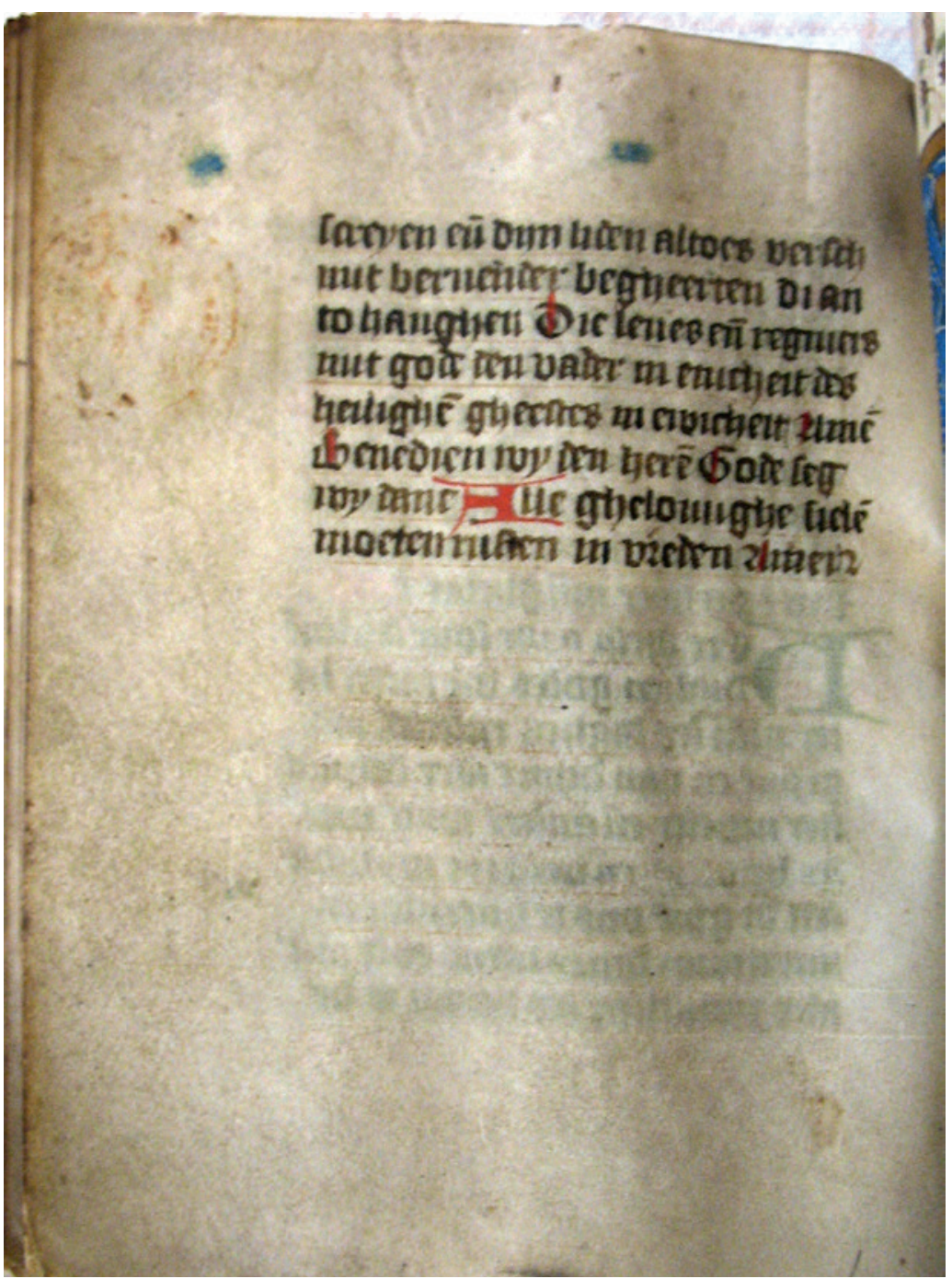

FIGURE 14.7 Opening page of the Hours of the Holy Spirit with the impression of a badge from Neuss (St Quirin) in a book of hours (probably IJssel area: ca. 1460-1485). Arnhem, Erfgoedcentrum Rozet, MS GM 2037, fol. $76 \mathrm{v}$

PHOTO BY THE AUTHOR 
the left hand to leaf through the pages. In this book, it seems that the badges were used to mark favourite and much-used passages. Notably, badges were not placed next to the Penitential Psalms nor the Hours of Eternal Wisdom, indicating that these were used less, or were less popular, with this book owner.

Other owners had different preferences. In another book, equally sparsely decorated, (British Library, Arundel MS 294), the owner marked only the Hours of Eternal Wisdom with a badge, leaving all the other book sections unmarked. ${ }^{30}$ In a book of hours in Dutch (The Hague, National Library of the Netherlands, MS ${ }_{135}$ E 22) the owner attached badges to the opening of the Hours of the Cross and to the prayer to the seventy-two names of the Virgin. In another book in Nijmegen University Library (MS 320) the owner had very specific intentions. They added badges to the sext of the Hours of Christ's Passion and of the House of the Virgin, and to the prime and none of the Hours of the Virgin, which seems in line with the idea that not every lay devotee had the time to read all the hours, but made a selection of hours that suited their schedule. ${ }^{31}$ Badges in the right places, adding relief and visual contrast to the page, helped to retrieve those selected passages when needed.

In a book of hours for the Use of Paris, the so-called 'Heures de Charles viII', the owner added a round badge of Le Puy. ${ }^{32}$ The badge was added to the lower margin of folio $32 \mathrm{v}$. The page still shows the sewing holes for the badge. The offset of the obverse on the following page [Fig. 14.8] shows the oblong lines of the narrow canopy, called the chadaraita, that was placed over the miraculous statue of the black Virgin in Le Puy. A comparison with the badge of Le Puy in the printed book of hours reveals the similarities [Fig. 14.1].33 The impression in the lower margin was left by a round badge that has the same narrow canopy that characterizes badges from Le Puy as the one in the printed hours. The badge, now gone, marked the incipit page (i.e. the page with the opening line) of the prayer Je te salve madame saincte marie. Significantly, the prayer of Guillaume Alexis, usually associated with the Virgin of Le Puy, starts on

3o British Library, Catalogue of Illuminated Manuscripts, URL: <https://www.bl.uk/ catalogues/illuminatedmanuscripts $>$ [accessed 4 August 2015].

31 Pantin W.A., "Instructions for a Devout and Literate Layman", in Alexander J.J.G. - Gibson M.T. (eds.), Medieval Learning and Literature: Essays Presented to Richard William Hurt (Oxford: 1976) 398-422, here 179; Brereton G.E. - Ferrier J.M., Le Menagier de Paris (Oxford: 1981) 6-9; Oosterman J.B., De Gratie van het Gebed: Overlevering en Functie van Middelnederlandse Berijmde Gebeden, vol. 1 (Amsterdam: 1995).

For the digitized version of this manuscript, see BnF Gallica, <http://gallica.bnf.fr> [accessed 17 June 2016].

Barral i Altet X. (ed.), La Cathédrale du Puy-en-Velay (Paris: 2000) 134-135. 


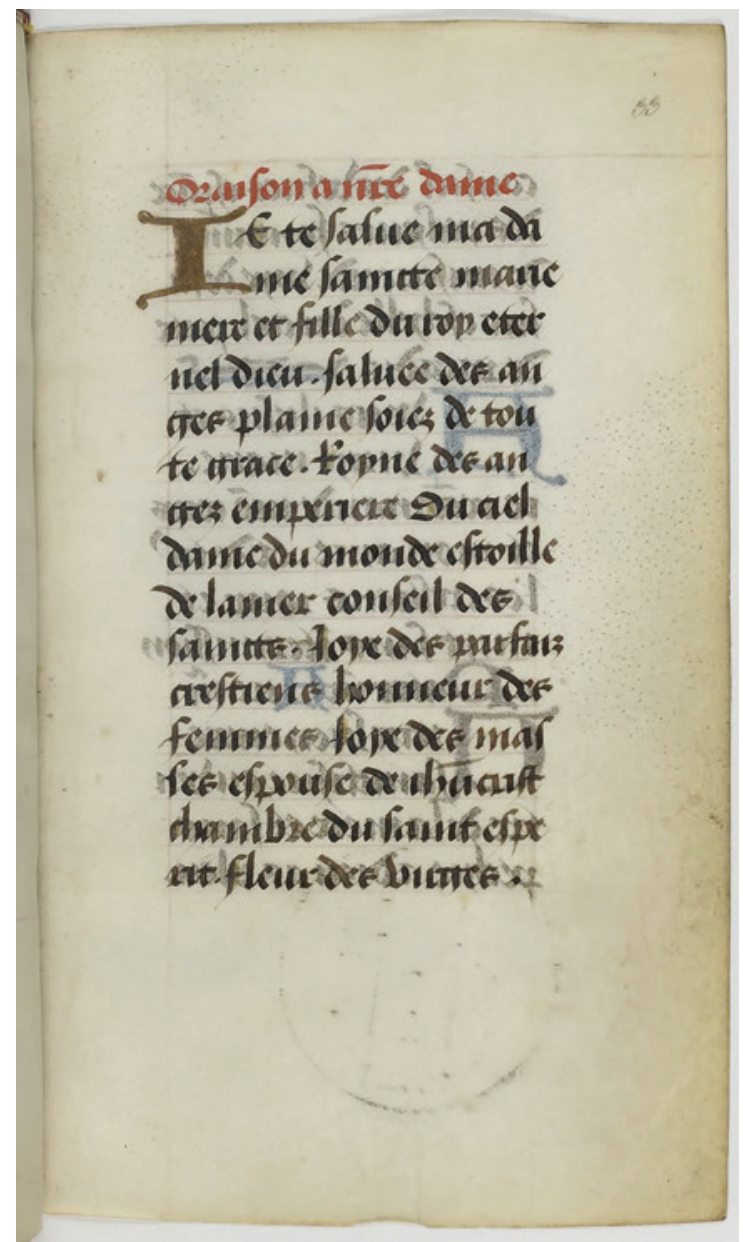

FIGURE 14.8 Page with Je te salve and impression of a badge of Le Puy in a book of hours for the Use of Paris, called 'Heures de Charles vinI', with a calendar for Tours (ca. 1475-1500). Paris, Bibliothèque nationale de France, MS Latin 1370, fol. 33r. Source gallica.bnf.fr / Bibliothèque nationale de France

folio 39v, but the book owner did not choose the margin of this incipit page on which to place the badge of Le Puy. The badge of the Virgin fits the prayer Je te salve where the Virgin is greeted as 'mother and daughter of the eternal king', 'queen of the angels', 'empress of heaven', and 'lady of the world'. The badge depicts her as a mother and as a queen enthroned. Further on, the devotee focuses on the Virgin and her Son who is also depicted on the badge. 
Notably, the book owner also established a link between badges and the text that occurs later in the book. Five diamond-shaped badges, reminiscent of the surviving badges of Thomas Becket of Canterbury, have left impressions on the page preceding the prayer to Thomas of Canterbury (fol. 214v). ${ }^{34}$ The badges were not attached to this page. They have also left impressions on the page with the prayer (fol. 215r). There, the devotee implores 'God for whose church the glorious pontiff Thomas fell dead through the sword of the impious'. ${ }^{35}$ It seems that the badges were attached to a separate piece of parchment that was added between folios 214 and 215 .

The badges brought into relief the texts that have no miniatures. The prayer to the Virgin has no differentiating rubric. Both the Je te salve and the Royne qui fustes mise are introduced by the words 'Oraison a nre dame' [Prayer to Our Lady], making no distinction between the two. Nothing sets these prayers apart to make it easier for the book owner to retrieve one or other of them. The badge made a difference. In line with the enormous popularity of the Virgin, prayers to the Virgin were the most popular passages to attach badges to. Traces of badges often appear next to the opening lines of the Obsecro Te to be found in many religious books for laypeople, and next to other prayers dedicated to the Virgin. ${ }^{36}$ The most prominent section dedicated to the Virgin in a book of hours was the Hours of the Virgin, ${ }^{37}$ and not surprisingly, badges were often added to the opening of this section. The Hours of the Cross were also popular,

34 Kunera, nos. 03114, and 09315 <http://www.kunera.nl> [consulted 20 June 2016].

35 Paris, Bibliothèque nationale de France, MS. Latin 1370, fol. 215r: 'Deus pro cuius ecclesia gloriosus pontifex thomas gladijs impiorum occubuit [...]'

36 Examples of manuscripts with badges next to prayers to the Virgin: Baltimore, Walters Art Museum, MS 262, fol. 132v; Brussels, Bibliothèque Royale de Belgique, Mss 8645, fol. 71v; MS.11 035-37, fol. 87v and IV 1096, fol. 31r; Oxford, Bodleian Library, MS Douce 51, fol. 59r; Olim Christie's, 4 June 2008, Lot 47, fol. 2ov; Paris, Bibliothèque nationale de France, MS Latin 1370, fol. 32v; The Hague, National Library of the Netherlands, MS 132 G 38, fol. 124v; Utrecht, Museum Catharijneconvent, MS Aвм h23, fols. 52v-53r.

37 Manuscripts with badges next to the Hours of the Virgin: Arnhem, Erfgoedcentrum De Rozet, MS GM 2037, fol. 12v; Baltimore, Walters Art Museum, MS W 782, (folio preceding) fol. 14v; Cologne, Diözesan- und Dommuseum, MS 1576, fol. 28v; Ghent University Library, MS BHSL.HS.2750, fol.28v; Nijmegen, Radboud University Library, MSs 203, fol. 5v, 283, fol. 8r, and 320, fols. 44v and 54v; Olim London, Christie's, 24 November 2007, Lot 10, fol. 12v; Paris, Bibliothèque nationale de France, MS Nouvelle Acquisition Latin 3213, fol. 18v; Utrecht, Museum Catharijneconvent, MS вмн h63, fol. 16v. Kathryn Rudy also concluded that the Hours of the Virgin were popular for the inclusion of badges. She argued, however, that the badges sewn to the Hours of the Virgin must have been Eucharistic wafer souvenirs because of the association of this text with the Incarnation. Rudy, "Sewing the Body" section C. 
although less so than the Hours of the Virgin. ${ }^{38}$ Some of the badges might have had an image that suited the text, but this was not necessarily the case. Badges with other religious images could suit the purpose of place marker just as well. Any religious badge sufficed, whether it was a pilgrims' badge or not, a souvenir of the book owner's own pilgrimage, or a gift.

\section{$5 \quad$ Storing the Badge, Shaping the Book}

It is clear that several false premises have obscured the study of badges in books. Firstly, although most badges in books are pilgrimage souvenirs, not all of them are. Some were not connected with a pilgrimage, but were religious medals. Secondly, the badges in books were not necessarily attached by the pilgrim: they were often given away as tokens of affection. And thirdly, their place in the book is often not indicative of their provenance or image. Although sometimes people did position a badge next to a relevant text or image, their place in the book should never be used to identify a missing badge. Hypothesizing about the use of badges as instruments for mental pilgrimage is justifiable, but caution is necessary when it comes to books where impressions are unclear. Placement next to a prayer to the Virgin does not imply that the badge was a pilgrimage souvenir. Equally, location next to a communion prayer does not imply an image of the host.

Although some laypeople might have used their (pilgrims') badges for mental pilgrimage, or - more specifically - for prayer in front of a cult image, not all of the badges functioned in this way. First of all, pilgrimage badges remained inextricably connected with the place of pilgrimage. They provided devotees with a cult image - a reliquary, a miracle-working statue or icon - connected with a specific site, and these badges could in theory be used to address the cult image in prayer if the devotee was not present at the cult site. While devotees prayed before the image at home they could mentally place themselves

38 Examples of manuscripts with badges attached to the Hours of the Cross include Arnhem, Erfgoedcentrum Rozet, MS GM 2037, fol. 53v; Brussels, Bibliothèque royale de Belgique, MS 10 541, fols. 10v and 13v; Ghent, University Library, MS BHSL.HS.2750, fol. 2ov; Nijmegen, Radboud University Library, MS 203, fol. 55v; The Hague, National Library of the Netherlands, MSS 135 E 22, fol. 103v, and B PH 137, fol. 13v; Utrecht, University Library, MS 15.C.9, fol. 91r. Rudy, "Sewing the Body" section B. Significantly, in most of these books the owner also added badges to another passage dedicated to the Virgin. Cf. previous notes. 
in front of the venerated image at the cult site. Religious medals that do not depict a cult image and that cannot be connected to a site of pilgrimage could not be used for mental pilgrimage in the same way. They also depict a saint or the Virgin, but are not connected with a place. Secondly, badges, both religious badges and pilgrims' souvenirs, were frequently used as bookmarks to identify favourite passages, so when a badge marks a text this does not necessarily mean it was used as an instrument for mental pilgrimage.

These comments aside, badges still reveal much about the devotional activities of the book owner. Badges differ from other additions to books, such as prints and small drawings, because they added relief to the pages. Even if the badges have left unrecognizable impressions, they can still be recognized as traces of medals. It is often only these remaining traces on the pages that reveal that the book owners had carefully assigned a place to their badges. These imprints, adhesive residue and needle holes indicate that different devotees used their badges to stress that their book was important to them. Badges were attached to blank pages to add devotional content, often of a very personal nature as the printed Paris hours indicated. Sometimes, badges were added to pages of text to accentuate and mark favourite passages. They indicate how books were used and which texts were the owner's favourites.

From the badge traces it becomes clear, as Rudy has noted, that devotees did not read these books from A to Z, but used some parts more extensively then others. Owners did not read the prayers at each liturgical hour of the day, but fell back on familiar prayers at one or two particular moments of the day. People had religious routines which depended largely on personal preferences and could vary significantly from one person to another. After their attachment, the religious badges became intricate and essential parts of the religious manuscript that developed, almost organically, into a shrine of personal devotion, at least for the owner who attached them. The religious manuscript for devotional use was never something fixed or finished; it was dynamic and flexible as memory that could slowly but surely be filled with knowledge. Books often remained in use and continued to be adapted and expanded after the book had been donated or bequeathed to family members, but badges were eventually removed from the pages, whether because attitudes towards pilgrimage and veneration of saints had changed during the Reformation, because their significance had been lost to later owners or because they came to be regarded as improper additions to the book. Even in their absence, the objects disclose the ways in which devotees carefully shaped their devotional lives. 


\section{Appendix}

Structure of the first quire in Chantilly, Impr XIV C.3 (fols. 1-8)

\begin{tabular}{|c|c|c|}
\hline Folios & Text and miniatures & Additions \\
\hline $1^{r}-2^{v}$ & Blank & $\begin{array}{l}\text { badges of the Virgin and } \\
\text { St Claude on fol. } 1 \mathrm{v}\end{array}$ \\
\hline $3 r$ & Full-page miniature: Coats of arms & \\
\hline $3 v$ & Blank & \\
\hline $4 \mathrm{r}$ & Full-page miniature: Coats of arms & \\
\hline $4 \mathrm{v}$ & $\begin{array}{l}\text { Full-page miniature: The Virgin and Child } \\
\text { with coat of arms of Chilly }\end{array}$ & \\
\hline $5^{r}$ & $\begin{array}{l}\text { Full-page miniature: Louis Allemand presents } \\
\text { male devotee wearing tunic of Chilly }\end{array}$ & \\
\hline $5^{v-6 r}$ & Prayers to Louis Allemand & \\
\hline $6 v$ & Blank & \\
\hline $7 \mathrm{r}$ & Full-page miniature: St Claude & \\
\hline $7 \mathrm{v}-8 \mathrm{r}$ & Prayers to St Claude & \\
\hline $8 v$ & Blank & \\
\hline
\end{tabular}

\section{Bibliography}

Arnaud D’Agnel G., Comptes du Roi René (Paris: 1910).

Asperen H. van, "Où il y a une Veronique attachiée dedens: Images of the Veronica in Religious Books", in Murphy A. - Kessler H.L. (eds.), The European Fortune of the Roman Veronica in the Middle Ages, Convivium Supplementum 2 (Leiden: 2018).

Asperen H. van, “'As If They Had Physically Visited the Holy Places': Two SixteenthCentury Manuscripts Guide a Mental Journey through Jerusalem (Nijmegen University Library, Mss 205 and 233)", in Goudeau J. - Verhoeven M. - Weijers W. (eds.), The Imagined and Real Jerusalem in Art and Architecture (Leiden: 2014) 190-214.

Asperen H. van, Pelgrimstekens op Perkament. Originele en Nageschilderde Bedevaartssouvenirs in Religieuze Boeken (ca 1450-ca1530), Nijmeegse Kunsthistorische Studies 16 (Ede: 2009).

Barral i Altet X. (ed.), La Cathédrale du Puy-en-Velay (Paris: 200o).

Beebe K., "Reading Mental Pilgrimage in Context: The Imaginary Pilgrims and Real Travels of Felix Fabri's 'Die Sionpilger”, Essays in Medieval Studies 25 (2008) 39-70. 
Brereton G.E. - Ferrier J.M., Le Menagier de Paris (Oxford: 1981).

Carruthers M., The Book of Memory: A Study of Memory in Medieval Culture (Cambridge - New York: 1992).

De Laborde L., Les Ducs de Bourgogne. Études sur les Lettres, les Arts et l'Industrie pendant le XVe Siècle et Plus Particulièrement dans les Pays-Bas et le Duché de Bourgogne, vol. 2, part 2 (Paris: 1851).

De Mecheleer L., Rekeningen van de Kerkfabriek van de Sint-Leonarduskerk van Zoutleeuw (1405, 1452-1599) (Brussels: 1997).

Deys H.P., "De Pelgrimsinsignes van Sinte Cunera te Rhenen”, Jaarboek Oud-Utrecht 67 (1994) 33-54.

Ehrenschwendtner M.-L., "Virtual Pilgrimages? Enclosure and the Practice of Piety at St Katherine's Convent, Augsburg", Journal of Ecclesiastical History 6o, 1 (2009) 45-73.

Enno van Gelder H.A., Gegevens Betreffende Roerend en Onroerend Bezit in de Nederlanden in de 16e Eeuw (The Hague: 1972-1973).

Foster-Campbell M.H., "Pilgrimage through the Pages: Pilgrims' Badges in Late Medieval Devotional Manuscripts", in Blick S. - Gelfand L.D. (eds.), Push Me, Pull You. Imaginitive, Emotional, Physical, and Spatial Interaction in Late Medieval and Renaissance Art (Leiden: 2011) 227-274.

Gay V., Glossaire Archéologique du Moyen-Âge et de la Renaissance, vol. 1 (Paris: 1887). Koldeweij A.M., "Reliekhoofden en Pelgrimstekens. Nieuws over de Utrechtse Zilversmid Cornelis van Noert", in Rijen J.-P. van - Bergh-Hoogterp L.E. van den Roessingh J.R.H. (eds.), De Stavelij in Zilver: 25Jaar Zilverclub (S.l.: 2000) 31-37.

Oosterman J.B., De Gratie van het Gebed: Overlevering en Functie van Middelnederlandse Berijmde Gebeden, vol. 1 (Amsterdam: 1995).

Pantin W.A., "Instructions for a Devout and Literate Layman", in Alexander J.J.G. Gibson M.T. (eds.), Medieval Learning and Literature: Essays Presented to Richard William Hurt (Oxford: 1976) 398-422.

Perkinson S., "Likeness, Loyalty, and the Life of the Court Artist: Portraiture in the Calendar Scenes of the Très Riches Heures", in Dückers R. - Roelofs P. (eds.), The Limbourg Brothers: Reflections on the Origins and the Legacy of Three Illuminators from Nijmegen (Leiden: 2009) 51-84.

Reinburg V., French Books of Hours: Making an Archive of Prayer, c. 1400-160o (Cambridge: 2012).

Reinburg V., "Hearing Lay People's Prayer", in Diefendorf B.D. - Hesse C. (eds.), Culture and Identity in Early Modern Europe (1500-180o): Essays in Honor of Natalie Zemon Davis (Ann Arbor: 1993) 20-40.

Rudy K.M., "Sewing the Body of Christ: Eucharistic Wafer Souvenirs Stitched to Fifteenth-Century Manuscripts Primarily in the Netherlands", Journal of the Historians of Netherlandish Art 8, 1 (2016), DOI: 10.5092/jhna.2016.8.1.1. 
Rudy K.M., Virtual Pilgrimages in the Convent: Imagining Jerusalem in the Late Middle Ages (Turnhout: 2011).

Rudy K.M., "A Guide to Mental Pilgrimage: Paris, Bibliothèque de l'Arsenal Ms. 212", Zeitschrift für Kunstgeschichte 64, 6 (2000) 494-515.

Spencer B.W., Pilgrim Souvenirs and Secular Badges, Medieval Finds from Excavations in London 7 (London: 1998).

Vorsterman van Oyen G.A., Het Archief van Aardenburg (Middelburg: 1889).

\section{Databases and Online Collections}

BnF Gallica, Bibliothèque nationale de France, Paris <http://gallica.bnf.fr >.

Catalogue of Illuminated Manuscripts, British Library, London <www.bl.uk/catalogues/ illuminatedmanuscripts $>$.

Kunera, Database of Medieval Badges and Ampullae, Radboud University Nijmegen, $<$ http://www.kunera.nl $>$. 